\title{
Diffusion of fair value measurement (IFRS 13): Perception of Auditors
}

\section{Difusión de la medición del valor razonable (NIIF 13): percepción de los auditores}

\author{
Babajide Oyewo* \\ University of Lagos, Nigeria \\ Received August 25, 2018; accepted March 21, 2020 \\ Available online May 9, 2020
}

\begin{abstract}
This study investigates the diffusion of fair value measurement (IFRS 13), with a focus on extent of application, and valuation methods used by reporting entities in Nigeria. Data-collection was through a structured questionnaire administered on 400 auditors from diverse backgrounds in terms of audit firm size, international affiliation, and global presence. Analysis of data obtained from 277 respondents, using descriptive statistics and one-way ANOVA, reveals that the overall extent of application of fair value measurement is moderate. However, there is significant difference in application level among reporting entities in the valuation of financial assets, financial liabilities, investment property, and goodwill \& intangibles acquired in business combination, but no significant difference in the valuation of pension liabilities, endowment funds, share-based payments, property, plants \& equipment, and land $\&$ building. It appears the level of investment in an asset/liability determines the application rate of fair value measurement - while high level of investment in an asset/ liability prompts extensive application, low level of investment correspondingly results into negligible usage. Further, the overall application rate of the valuation methods is in the descending order of: market, expert estimation, cost and income approaches respectively. The market and cost approaches are applied more extensively in the valuation of tangible assets; the market approach is preferred in the valuation of financial instruments, while expert estimation is more applicable in the valuation of intangible assets and liabilities. Given that the market
\end{abstract}

\footnotetext{
*Corresponding author.

E-mail address: meetjidemichael@gmail.com (B. Oyewo).

Peer Review under the responsibility of Universidad Nacional Autónoma de México.
} 


\section{B. Oyewo / Contaduría y Administración 66(2) 2021, 1-33 \\ http://dx.doi.org/10.22201/fca.24488410e.2021.2178}

approach is the predominant valuation method, the study calls on relevant authorities and concerned stakeholders to emplace institutional apparatus that will facilitate the ready availability of fair value prices for accounting items.

JEL Code: M41, M42

Keywords: Fair value; Historical cost; Financial reporting quality; IFRS 13; Valuation methods

\section{Resumen}

Este estudio investiga la difusión de la medición del valor razonable (NIIF 13), con un enfoque en el alcance de la aplicación y los métodos de valoración utilizados por las entidades informantes en Nigeria. La recopilación de datos se realizó a través de un cuestionario estructurado que se administró a 400 auditores de diversos orígenes en términos de tamaño de la firma de auditoría, afiliación internacional y presencia global. El análisis de los datos obtenidos de 277 encuestados, utilizando estadísticas descriptivas y ANOVA de una vía, revela que el alcance general de la aplicación de la medición del valor razonable es moderado. Sin embargo, existe una diferencia significativa en el nivel de aplicación entre las entidades informantes en la valoración de activos financieros, pasivos financieros, propiedades de inversión y fondo de comercio e intangibles adquiridos en combinación de negocios, pero no hay diferencias significativas en la valoración de pasivos por pensiones, fondos patrimoniales, acciones. pagos basados en propiedades, plantas y equipos, y terrenos y edificios. Parece que el nivel de inversión en un activo / pasivo determina la tasa de aplicación de la medición del valor razonable, mientras que un alto nivel de inversión en un activo / pasivo genera una aplicación extensa, el bajo nivel de inversión da como resultado un uso insignificante. Además, la tasa de aplicación general de los métodos de valoración está en el orden descendente de: mercado, estimación de expertos, enfoques de costos e ingresos, respectivamente. Los enfoques de mercado y de costos se aplican de manera más amplia en la valoración de activos tangibles; Se prefiere el enfoque de mercado en la valoración de instrumentos financieros, mientras que la estimación experta es más aplicable en la valoración de activos y pasivos intangibles. Dado que el enfoque de mercado es el método de valoración predominante, el estudio hace un llamado a las autoridades relevantes y las partes interesadas interesadas para ubicar un aparato institucional que facilite la disponibilidad inmediata de precios de valor razonable para los elementos contables.

\section{Código JEL: M41, M42}

Palabras clave: Valor razonable; Costo histórico; Calidad de los informes financieros; NIIF 13; Métodos de valoración ; Employee loyalty 


\section{Introduction}

The debate on the quality of accounting information has continued to attract much research attention, perhaps because users of performance reports have been unrelenting in their clamour for improvement in the quality of information on which they base their economic decisions. The call for improvement in quality of accounting information also stems from the divergent roles it performs, including but not limited to: conveying information to assist decision-makers and providers of funds in resource-allocation (Akinsulire, 2010; Melville, 2011); dispersing the clout created by information asymmetry between corporate managers and parties contracting with their firms (Ball, 2006); enhancing the development of financial systems, comprising of the financial intermediaries, money market, capital markets; and contributing to the rules regulating the flow of funds in the economy (Nwankwo, 1988; Ekiran, 2000; Akinsulire, 2010), among others. Considering that financial systems are sustained by the flow of accounting information (Osaze \& Anao, 1999; Chouinard \& Youngman, 2008), it is understandable that stakeholders seek continuous improvements in the quality of financial reports and other performance reporting documents.

Financial reports issued by reporting entities are mainstream amongst the various means available to communicate performance information to stakeholders. It is therefore crucial that they are of high quality if they are to serve the purposes for which they are rendered. To satisfy the information needs of users, financial reports are expected to possess certain qualitative characteristics such as relevance, verifiability, reliability, freedom from bias, comparability, consistency, and fruitful representation (Riauhi-Belkaoui, 2004; Deloitte, 2012; The International Accounting Standards Board, IASB, 2012). In achieving these qualitative characteristics, several approaches have been put forward to measure the elements of financial statements such as: historical cost, current cost, replacement cost, and fair value measurement (Deloitte, 2012; Kaplan, 2015). Unlike historical cost accounting which purports that assets and liabilities of a business should be captured in the books of account at the amount that the transaction was originally consummated, fair value accounting advocates that assets and liabilities should be recorded at current market value. Fair value measurement started gaining traction on account of issues surrounding the valuation of financial instruments (e.g. shares traded on an exchange, debt securities, and derivatives) because historical cost accounting could no longer accommodate the complexities inherent in such items as to ensure their faithful representation. Whereas historical cost accounting is thought to enhance reliability, it has been argued that fair value accounting emphasizes relevance of accounting information (Mirza, Orrel \& Holt, 2008; Oyewo, Emebinah \& Savage, 2020). The appropriateness of the measurement approach adopted, the correctness of the monetary values conferred on accounting items (i.e. assets, liabilities, equity, income and expenses) based on the selected 
measurement approach, and the subsequent recognition of accounting items as elements of financial reports all determine the overall quality of accounting information.

Determination of income is among the endeavours of companies that has been gaining prominence in recent times because the availability of income affects the ability of an organisation to discharge its responsibilities to various stakeholders (Ministry of Economics, Japan, 2014; Adams, 2015). In income determination circles, argument on fair value measurement is popular, as the use of fair value measurement is becoming widespread, transcending financial assets and financial liabilities to non-financial assets (International Auditing and Assurance Standards Board, IAASB, 2008). Whereas there were various International Accounting Standards (IASs) / International Financial Reporting Standards (IFRSs) that were dispersed which dealt in part with fair value measurement (e.g. IAS 39/IFRS 9 on financial assets and financial liabilities; IAS 41 on Agriculture), IFRS 13 was issued to extensively deal with fair value measurement. It replaces the inconsistent guidelines found in various IFRSs with a single source of guidance on measurement of fair value. This study concentrates on the fair value measurement concept as enshrined in IFRS 13 framework.

Contextually developed to measure financial instruments (Hague, 2002; Yichao, 2010), the application of IFRS 13 (fair value measurement) has been extended to non-financial items, thus establishing broadness in scope of coverage of the standard. The requirement of the standard (i.e. IFRS 13) that fair value measurement applies to both: (i) items recognized or incorporated in financial statements at fair value, and (ii) items not reported at fair value in financial statements but disclosed in notes to the account on fair value basis, reiterates the widening applicability of the standard, and its omnibus influence in determining financial reporting quality. However, the application of fair value measurement across various groups of assets and liabilities has not been without challenges. In lending credence to the problems of fair value measurement, IAASB (2008) notes that the breadth of assets and liabilities to which fair value accounting may be/ is required to be applied is one of the key issues in fair value measurement, as well as the choice and sophistication of acceptable valuation methods and models. Arguments against fair value measurement are that it is less objective, requires extensive use of judgement, and estimates arrived at are not easy to prove (Zack, 2009; Abdullatif, 2016).

Considering that reporting entities in Nigeria have adopted international accounting standards (including IFRS 13), it is necessary to investigate the diffusion of fair value measurement in the Nigerian context. Acknowledging that stakeholder-groups such as preparers of financial reports, management, shareholders, investors and auditors, amongst others, are interested in the quality of accounting information, this study focuses on external auditors as one of the important groups. Cardao-Pito \& Barros (2016, p. 78) contend that “...the specific effects of accounting policies and standards on different organisational stakeholders must be studied". 
Auditors contribute to the credibility of accounting information through their audit reports (Hermanson, Shrawer \& Shrawer, 1993; Gill \& Cossert, 2008; International Standard on Auditing, ISA 540, 2018). Auditors have responsibilities to ensure that fair value measurement and other accounting estimates are reasonable, and that related disclosure notes in financial statements are adequate (International Standard on Auditing, ISA 540, 2018).

Noting that literature on fair value accounting is scanty in Nigeria due to the newness of the concept, some of the few empirical studies have focused on issues such as prospects and challenges of fair value accounting (e.g. Okafor \& Ogiedu, 2012; Appah, 2018), impact of fair value measurement on reported profit (e.g. Bessong \& Charles, 2012), and impact of fair value measurement on financial reporting quality (e.g. Jafaru \& Shodipo, 2013; Ijeoma, 2014). Other post-implementation issues surrounding IFRS 13 adoption such as level of application of fair value measurement and valuation methods used by reporting entities are yet to be rigorously investigated as little is known in these areas. Against this backdrop, the current study investigates the application of fair value measurement and accounting estimates in the Nigerian context from the perspective of external auditors. A study from Nigeria, as one of the leading economies in sub-Sahara Africa, on the diffusion of fair value measurement is crucial in providing a broader view on the implementation of fair value accounting in the post-IFRS adoption era. Nigeria joined the league of other nations that have adopted IFRS standards (including IFRS 13), as it would be in the interest of the Nigerian economy for reporting entities to apply globally accepted, high-quality accounting standards. Findings from the study of Nigeria as a country with one of the largest economies in Africa could be compared with studies conducted in other jurisdictions to gain a deeper insight into the application of fair value measurements. Such knowledge could inform financial reporting standards review and/ or shape accounting policy formulation in reporting entities. Therefore, the objectives of the current study are to; (i) determine the extent of application of fair value measurement; and (ii) ascertain the valuation methods used for estimating fair value of assets and liabilities by reporting entities in Nigeria.

To achieve the research objectives, survey research design was adopted. Considering that the study focused on the perception of external auditors, the use of questionnaire as a data-collection technique under the survey method (as opposed to content-analysing the financial statements of reporting entities) is adjudged appropriate. Analysis of empirical data obtained from 277 auditors, using descriptive statistics and one-way ANOVA, reveals that the overall extent of application of fair value measurement is moderate. However, there is significant difference in the application level among reporting entities in the valuation of financial assets, financial liabilities, investment property, and goodwill \& intangibles acquired in business combination, but no significant difference in the valuation of pension liabilities, endowment funds, share-based payments, property, plants \& equipment, and land \& building. Further, 
the overall application rate of the valuation methods is in the descending order of: market, expert estimation, cost and income approaches respectively. Given that the market approach is the predominant valuation method, the study calls on relevant authorities and concerned stakeholders to emplace institutional apparatus that will facilitate the ready availability of fair value prices for accounting items.

The rest of the paper has five sections. Literature review and hypothesis development are covered in Section 2. Methodology is explained in Section 3. Results and Discussion of findings are presented in Sections 4 and 5 respectively. The paper is concluded in Section 6.

\section{Literature review}

\section{Fair value as a measurement basis}

Depending on the context, different definitions have historically been adduced for fair value. The International Accounting Standards Board (IASB) definition as contained in IFRS 13 framework is that fair value is "the price that would be received to sell an asset or paid to transfer a liability in an orderly transaction between market participants at the measurement date". This definition assumes the existence of an exit price. It is expected that the asset will be put out for sale in a market most advantageous to sell the asset or transfer the liability such that the seller maximizes the amount to be received for the asset or minimizes the cost to be incurred to transfer the liability. The most advantageous exit price can be achieved by exposing the asset or liability to the market for a period before the date of measurement to allow for normal marketing activities to take place and to ensure that it is not a forced transaction between market participants. Market participants are independent, knowledgeable and willing buyers and sellers operating in the most advantageous market.

The debate on fair value accounting is still unsettled. Although fair value measurement has gained noticeable level of acceptance globally, its introduction has been greeted with resistance in some quarters. While proponents of fair value accounting contend that fair value measurement provides a guide in ascertaining the 'correct' value of accounting items - particularly non-monetary assets and liabilities (Cardao-Pito \& Barros, 2016; Laux \& Leuz, 2009; Antunes \& Alves, 2008; Mirza et al., 2008), opposers counter that fair value accounting not only sacrifices reliability for relevance (Jermakowicz \& Gornik-Tomaszewski, 2006), but it is also subjectively and abusively used by less well-intentioned economic agents (Cardao-Pito, 2016; Danbolt \& Rees, 2008; Biondi \& Suzuki, 2007). Cardao-Pito \& Barros (2016), for instance, report that the adoption of fair value accounting caused tax revenue of Portugal to reduce due to negative adjustments to profit - the decision of tax authorities to revise tax 
codes, prohibiting the use of fair value accounting for taxation purpose is informed by the reduction of taxable profit occasioned by fair value measurement.

Since fair value measurement affects accounting items, it may not be surprising that fair value accounting has made inroads to various fields of accounting, such as financial reporting (Guthrie, Irving \& Sokolowsky, 2011; Barth \& Landsman, 1995), auditing (Griffin, 2014; International Auditing and Assurance Standards Board, IAASB, 2008), cost \& management accounting (Carroll, Linsmeier \& Petroni, 2003), and taxation (Cardao-Pito \& Barros, 2016). This development reiterates the pervasiveness of fair value as a measurement basis, and the burgeoning nature of fair value accounting as a research field. However, empirical studies on the application of fair value measurement are lacking (Bougen \& Young, 2012; Cardao-Pito $\&$ Barros, 2016). Cardao-Pito \& Barros (2016) draw attention to the need to investigate the impacts of fair value measurement on taxes and public revenues. This was against the background that the application of fair value standards became mandatory after 2005 for companies listed in European Stock Exchanges.

\section{Fair value measurement as an innovation}

Sequel to the adoption of IFRS by reporting entities in Nigeria in 2012, the requirement for the application of IFRS 13 on an annual basis, commencing on 1 January 2013 (Deloitte, 2012), became applicable to reporting entities in Nigeria. To the extent that fair value measurement is new to the Nigerian environment, the application of fair value measurement can arguably be conceived as an innovation. The study therefore invokes Roger's (2003) diffusion of innovation theory as the theoretical framework. Rogers (2003, p. 12) conceives innovation as "an idea, practice, or project that is perceived as new by an individual or other unit of adoption". Before IFRS adoption by reporting entities in Nigeria in 2012, the preparation of financial reports was guided by the Nigerian Statement of Accounting Standards (SASs) issued by the Nigerian Accounting Standards Board (NASB) since 1982 until July 20th, 2011 when the Financial Reporting Council Bill was signed into law (Jafaru \& Shodipo, 2013; Umoren \& Enang, 2015). Although most of the International Accounting Standards (IASs) issued by IASB had equivalent SASs (Yahaya et al., 2015), certain IASB standards had no equivalent SASs. One of such standards that was fundamentally different is fair value measurement (Blanchette \& Desfleurs, 2011; Chua \& Taylor, 2008).

Noting that fair value accounting has been in existence in developed countries (e.g. Europe, USA) before now (Cardao-Pito \& Barros, 2016; Laux \& Leuz, 2009), the advent of IFRS adoption birthed the application of fair value measurement in Nigeria. It therefore qualifies as an innovation going by Rogers' (2003) postulation. According to Rogers (2003), an innovation may have been invented a long time ago, but if individuals in a location, place 
or organisation perceives it as new, then it may be construed as an innovation for them. Today, reporting entities in Nigeria now render statement of profit or loss and other comprehensive income, which recognises unrealized gains and losses from performing a 'mark-to-market', underpinned by the application of fair value accounting.

\section{Valuation methods and level of inputs in fair value measurement}

When the price for an asset or liability cannot be observed directly, it must be estimated using a valuation method. With reference to IFRS 13 , to estimate the price of an asset or liability, there are a broad range of techniques available, namely; the market approach; cost ('replacement cost') approach and the income approach. The market approach is a valuation method that uses prices and other relevant information from market transactions involving comparable or identical assets and liabilities. The cost approach reflects the amount that would be required currently to replace the service capacity of an asset (Deloiite, 2012). Income approach converts future amounts (i.e. cash flows or income and expenses) to a single current amount. In addition to these three valuation methods, the standard permits the use of fair value estimates computed by experts, provided the valuation is arrived at in compliance with IFRS 13 guidance.

The three valuation methods (market, cost, and income approaches) require inputs in determining fair value. When measuring fair value, the entity is required to maximise the use of observable inputs and minimise the application of unobservable inputs. 'Observable inputs' are inputs that reflect the assumptions market participants would use in pricing the asset or liability, developed based on market data obtained from sources independent of the reporting entity. 'Unobservable inputs' are inputs that reflect the reporting entity's own assumptions about the assumptions market participants would use in pricing an asset or liability, developed based on the best information available in the circumstances. Thus, IFRS 13 introduces a fair value hierarchy, which categorises the inputs into the fair value measurement process in the descending order of priority, namely: "Level 1", "Level 2", and 'Level 3' inputs respectively. The categorisation of fair value measurement in the fair value hierarchy is based on the inputs and not the valuation methods used (Deloitte, 2012; IASB, 2012; Jayeoba \& Ajibade, 2016).

Level 1 inputs comprise unadjusted quoted prices in active markets for identical assets and liabilities that the entity can access at the measurement date. In other words, when there is direct market for the item, the obtained value is called fair value level 1 (Cardao-Pito \& Barros, 2016). As quoted price of an identical asset or liability provides the most reliable evidence of fair value, IFRS 13 recommends the use of "Level 1" inputs whenever available, without any adjustments to fair value except in certain circumstances. 
"Level 2" inputs comprise other observable inputs not included within "Level 1" of the fair value hierarchy. They are inputs other than quoted prices included within Level 1 that are directly or indirectly observable for an asset or liability, including quoted prices for similar assets or liabilities in active markets; quoted prices for identical or similar assets or liabilities in markets that are not active; and inputs other than quoted prices that are observable for the asset or liability. Level 2 input is used when there is a market for a product with some similarities and therefore used as a basis for comparison (Cardao-Pito \& Barros, 2016).

"Level 3" inputs comprise unobservable inputs (including the entity's own data, which are adjusted, if necessary, to reflect the assumptions market participants would use in the circumstances). IFRS 13 (cited in Deloitte, 2012, p. 358) defines active market as a "market in which transactions for the asset or liability take place with sufficient frequency and volume to provide pricing information on an ongoing basis". In essence, Level 3 makes use of a theoretical model to identify possible market prices, in the absence of a directly or indirectly comparable market (Cardao-Pito \& Barros, 2016).

Some scholars have argued that although fair value measurement may enhance relevance of financial reports (Ting \& Soo, 2005; Enahoro \& Jayeoba, 2013), it does not ease the comparability problem but may likely exacerbate it (Bessong \& Charles, 2012). The problem of comparability stems from arbitrariness in valuation where no market price exists (i.e. level 2 and level 3 inputs), and the non-availability of market price in countries. In such cases, firms use different valuation methods that consider a variety of relevant data. The different valuation methods will yield different fair values which jeopardises comparability.

\section{Areas of application of fair value measurement}

Fair value measurement applies to elements of financial statement such as financial assets and financial liabilities (Cardao-Pito \& Barros, 2016; Bell \& Griffin, 2012; Deloitte, 2012; IASB, 2012). Following the manner IFRS 13 was developed, fair value measurement can equally be applied to non-financial items, which could be individual asset and liability or a group of assets and liabilities. For non-financial assets, fair value is determined by considering how market participants would maximise the benefits from putting the assets to use (the 'highest and best use' concept). The fair value measurement of a liability, or the entity's own equity, assumes that it is transferred to a market participant at the measurement date-in such cases, there is no observable market to provide pricing information, and the 'highest and best use' concept does not apply. Other areas of application are: valuation of pension liabilities, goodwill and intangibles acquired in a business combination, real estate, investment property, property plant \& Equipment (PPE), biological assets, endowment funds, share-based payments, non-monetary exchanges and other classes of assets and liabilities (Cardao-Pito 
\& Barros, 2016; Yahaya, Fagbemi, \& Oyeniyi, 2015; Maruli \& Farahmita, 2011; IAASB, 2008). As reporting entities are at liberty to decide on the classes of assets and liabilities to which fair value measurement is applied (Guthrie et al., 2011), the level of application of fair value may expectedly be heterogenous across sectors. This leads to the hypothesis that:

H1: There is significant difference in the overall extent of application of fair value accounting by reporting entities in Nigeria based on auditors' perception

Firms operating in a sector may have higher concentration of certain assets/liabilities than others operating in other sectors. For instance, financial institutions may hold more financial instruments than other organisations, and may extensively apply fair value measurement in this area. The valuation method to be applied in arriving at fair value estimates will depend on the nature of assets and liabilities to be valued and the availability of information/required inputs (Levels 1, 2 and 3, respectively). Ascertaining the fair value of an asset using the market approach is less cumbersome in comparison to the cost- or income- approach owing to the availability of information and the procedures involved. While some assets (say tangible assets) may have "Level 1" direct market price readily available (as to facilitate the application of market approach), some other items (e.g. intangible assets and liabilities) may have unobservable "Level 3" input, thus necessitating the application of complex methods such as expert estimation or income approach. The availability (non-availability) of information for various accounting items would therefore encourage (dissuade) the application of fair value measurement. Companies operating in sectors with a high concentration of items that have readily available market prices would have greater propensity to apply fair value measurement in comparison to entities in sectors with high volume and value of items with no easily available market price. Thus, the level of application of fair value measurement for various accounting items may be sector-sensitive. This leads to the hypothesis that:

$\mathrm{H} 2$ : The application level of fair value measurement for accounting items significantly differ across sectors of reporting entities in Nigeria based on auditors' perception.

\section{Research methods}

Research design

The study adopted a survey research design. The population of the study is comprised of all external auditors in Nigeria. The list of audit firms registered with The Institute of Chartered 
Accountants of Nigeria (ICAN), the professional accounting body responsible for licensing auditors in Nigeria, initially guided the enumeration of practicing auditors. A list of firms involved in the audit of companies quoted on the mainboard of the Nigerian Stock Exchange was thereafter compiled from the inspection of published annual reports. Twenty-four (24) firms, including the Big 4 (4 firms) and non-Big 4 (20 firms) were selected. Data collection was by a structured questionnaire. Considering that the study focused on the perception of external auditors, the use of questionnaire as a data-collection technique under the survey method (as opposed to the analysis of annual reports of reporting entities) is considered appropriate.

Bearing in mind that the Big 4 have wider market share in providing attestation service (Okaro \& Okafor, 2013), fifty (50) copies of the questionnaire were distributed to each of the Big 4 and ten (10) copies distributed to every of the twenty (20) non-Big 4 firms for onward distribution to auditors involved in fair value audit. A total of four hundred (400) copies were distributed through the audit firms to individual auditors. Each auditor completed a copy of the questionnaire. Questionnaire administration lasted about three months, with follow-up visits and reminders at regular intervals during this period.

\section{Data collection instrument and measurement of variables}

The data collection instrument was designed to gather information on the research subject by requesting respondents to indicate their overall perception on the application of fair value measurement at the sector level (and not at organisational level for each of the audited company/reporting entity). This is because it is expected that the audit of various companies within a sector of an auditor's specialisation over the period would have exposed the auditor to the fair value accounting practices of reporting entities in that sector.

The questionnaire had two sections (A and B). Section A was subdivided into two subsections A1 and A2. Subsection A1 measured audit firm attributes such as size, affiliation to international audit firm, and global presence. Subsection A2 elicited data on respondent's profile (work experience and sector of audit specialisation).

Size of audit firm was operationalised using the number of partners. Categorisation of number of partners was guided by the class of license issued by The Institute of Chartered Accountants of Nigeria (ICAN). Firms were labelled as follows based on the number of partner(s): Sole Practitioners (1 Partner), Small firms (2-4 Partners), Medium firms (5-9 Partners) and Large firms (10 Partners and above). Affiliation to international audit firm was determined by requesting respondents to declare whether or not their firm was affiliated to international audit firms. Global presence was measured by segregating firms into big 4 and non-big 4 . The Big 4 audit firms (PwC, KPMG, Ernst \&Young, and Deloitte) enjoy more presence in 
the international scene than non-big 4 (Okaro \& Okafor, 2013) and they offer the highest attainable audit services due to their technical as well as professional capabilities (Bloom \& Schrim, 2008). The Big 4 are among the various international auditing and consulting firms that provide attestation for the genuine presentation of financial statements.

Auditor's length of work experience (in years) was in five categories of: Less than 3 , 3-6, 7-10, 11-15, and over 15 years respectively. Respondents were requested to indicate the sector they specialise in auditing from the following list (the sector classification for audit market purpose was gleaned from the websites of the big 4 and the non-big 4 audit firms): Manufacturing, Financial Service, Technology, Media \& Telecommunication, Oil \& Gas, Healthcare, Small \& Medium Scale Enterprises (SMEs), Energy, Agriculture/Agro-allied, and Other sectors (to capture any other sectors not enlisted).

Section B had two subsections (B1 and B2). Subsection B1 focused on ten areas of application of fair value (FV) measurement. Auditors were requested to rate the extent to which fair value measurement was applied by their clients (i.e. reporting entities) to value the following categories of assets and liabilities: (i) financial assets, (ii) financial liabilities, (iii) pension liabilities, (iv) goodwill \& intangibles acquired in business combination, (v) endowment funds, (vi) share-based payments, (vii) property, plants \& equipment, (viii) land \& building, (ix) investment property and (x) biological assets (animals and plants). Responses were calibrated on a 5-point scale of Not applied (1), Barely applied (2), Moderately applied (3), Extensively applied (4), and Very Extensive (5). Subsection B2 considered valuation methods for fair value estimates. After enumerating four valuation methods [Market approach (MV), Cost approach (CV), Income approach (IV), and valuation-expert approach (EX)], respondents were requested to indicate the technique applied by reporting entities for each of the ten categories of assets and liabilities. In anticipation that auditors may be unable to ascribe valuation methods to some items, a fifth option whereby respondents could indicate the non-applicability of the valuation methods (designated 'NA') was included in the valuation approaches.

\section{Validity and reliability of research instrument}

To ensure validity, the research instrument was constructed after an extensive review of extant literature. The initial draft of the questionnaire was submitted to a senior academic with competence in fair value accounting (FVA) and two senior auditors ( 1 from big 4 and another from a non-big 4 audit firm) specialising in fair value audit for critiquing. Feedbacks obtained from the three experts were used to refine the final version that was administered. The reliability of the research instrument was assessed using three measures of internal consistency - Cronbach's alpha, Guttman Split-Half Coefficient, and Kaiser-Meyer-Olkin 
(KMO) Measure of Sampling Adequacy (Table 1). The coefficients of the Kaiser-Meyer-Olkin Measure of Sampling Adequacy (in appendix 1) are 0.711 and 0.705 for Areas of Application and Valuation Methods respectively, both significant at $1 \%$.

Table 1

Reliability test results

\begin{tabular}{lcccc}
\hline \multicolumn{1}{c}{ Variable } & $\begin{array}{c}\text { Number of } \\
\text { items }\end{array}$ & $\begin{array}{c}\text { Cronbach's } \\
\text { Alpha }\end{array}$ & $\begin{array}{c}\text { Guttman Split-Half } \\
\text { Coefficient }\end{array}$ & $\begin{array}{c}\text { Kaiser-Meyer-Olkin } \\
\text { Measure of Sampling } \\
\text { Adequacy. }\end{array}$ \\
\hline $\begin{array}{l}\text { Areas of applica- } \\
\text { tion of FVA }\end{array}$ & 10 & .802 & .689 & $.711^{*}$ [appendix 1] \\
$\begin{array}{l}\text { Valuation methods } \\
\text { for FVA }\end{array}$ & 10 & .755 & .656 & $.705^{*}$ [appendix 1] \\
\hline
\end{tabular}

*significant at $1 \%$

Respondents' attrition and response rate

From the four hundred (400) copies of the questionnaire administered, two hundred and eighty-three (283) copies were retrieved, representing a response rate of 70.75\%; 6 copies were found unsuitable for use because of incomplete response to some items, reducing the number of usable copies to two hundred and seventy-seven (277) [representing an effective response rate of $69.25 \%$ ] which were processed for analysis. Non-response bias was assessed by comparing the first $20 \%$ of responses obtained with the last $20 \%$ responses received, using global presence (big 4/ non-big 4) as a basis for comparison of early response with late response. Independent sample t-test result shows no significant difference at $1 \%(p=.837>$ .01 ), thus confirming the absence of non-response bias.

\section{Method of data analysis}

Descriptive and inferential statistics were applied in data analysis. Descriptive statistical techniques used were frequency count, percentage analysis, range (minimum and maximum values), Mean (M) and standard deviation (SD). Inferential statistics applied was the one-way Analysis of Variance (ANOVA). 


\section{Results}

Audit firm attributes and respondents' profile

Table 2

Audit Firm Attributes and Respondents' Profile

\begin{tabular}{|c|c|c|c|c|}
\hline Variable & Category & Freq. & $\%$ & Total \\
\hline \multirow[t]{4}{*}{ Size (No. of Partners) } & 1 & 15 & 5.4 & \\
\hline & $2-4$ & 39 & 14.1 & \\
\hline & $5-9$ & 80 & 28.9 & \\
\hline & $10 \&$ Above & 143 & 51.6 & 277 \\
\hline \multirow{2}{*}{$\begin{array}{l}\text { Affiliation to International } \\
\text { Audit firm }\end{array}$} & Affiliated & 244 & 88.1 & \\
\hline & Not Affiliated & 33 & 11.9 & 277 \\
\hline \multirow[t]{3}{*}{ Global Presence } & Big-4 & 143 & 51.6 & \\
\hline & Non-Big 4 & 134 & 48.4 & 277 \\
\hline & Less than 3 years & 66 & 23.8 & \\
\hline \multirow{4}{*}{$\begin{array}{l}\text { Length of work Experience as } \\
\text { External Auditor }\end{array}$} & 3-6 years & 109 & 39.4 & \\
\hline & $7-10$ years & 56 & 20.2 & \\
\hline & $11-15$ years & 34 & 12.3 & \\
\hline & Over 15 years & 12 & 4.3 & 277 \\
\hline \multirow[t]{7}{*}{ Auditor Sector specialisation } & Manufacturing & 50 & 18.1 & \\
\hline & Financial Service (Bank \& Non-bank) & 54 & 19.5 & \\
\hline & Technology, Media \& Telecom. & 52 & 18.8 & \\
\hline & Oil \& Gas & 45 & 16.2 & \\
\hline & Small \& Medium Scale (SMEs) & 35 & 12.6 & \\
\hline & Energy & 24 & 8.7 & \\
\hline & Agriculture./Agro-allied & 17 & 6.1 & 277 \\
\hline
\end{tabular}

Result on Audit Firm Attributes in Table 2 shows that respondents from audit firms of various sizes participated in the study. $15(5.4 \%)$ respondents were from sole practice firms, 39 (14.1\%) from small firms, 80 (28.9\%) from medium firms and 143 (51.6\%) from large audit firms. $244(88.1 \%)$ of the respondents were from internationally-affiliated firms while $33(11.9 \%)$ were from indigenous firms with no international affiliation. $143(51.6 \%)$ of the auditors were from the big 4 and 134 (48.4\%) from non-big 4. Majority of the respondents have work experience of 3-6 years $(109,39.4 \%), 66$ (23.8\%) have less than 3years experience; $56(20.2 \%), 34(12.3 \%)$, and $12(4.3 \%)$ respondents have work experiences of 7-10 years, 
11-15 years and over 15 years respectively. Overall, $175(63.2 \%)$ have no more than 6 years work experience, while $102(36.8 \%)$ have over 6 years of experience. $50(18.1 \%)$ respondents specialise in the audit of manufacturing firms, $54(19.5 \%)$ in the audit of financial service sector, and 52 (18.8\%) in Technology, Media and Telecommunications audit. 45 (16.2\%), 35 (12.6\%), 24 (8.7\%) and 17 (6.1\%) specialise in the audit of Oil \& Gas, Small \& Medium Scale Enterprises (SMEs), Energy and Agriculture /Agro-allied firms respectively. Overall, result in Table 2 shows that the views of auditors from diverse backgrounds in terms of audit firm size, international affiliation, and global presence were obtained.

\section{Extent of application of fair value measurement in specific areas}

Result on the extent of application of fair value measurement to various categories of assets and liabilities is reported in Table 3. Items are ranked in the descending order of Mean score.

Table 3

Extent of Application of FVA by Reporting Entities in Nigeria

\begin{tabular}{llccc}
\hline S/N & \multicolumn{1}{c}{ Item } & Range & Mean & SD \\
\hline 1 & Valuation of Investment Property & $1-5$ & 3.83 & 1.016 \\
2 & Valuation of Financial Assets & $1-5$ & 3.74 & 1.059 \\
3 & Valuation of Biological Assets (Animals \& Plants) & $1-5$ & $3.71^{*}$ & 1.213 \\
4 & Valuation of Financial Liabilities & $1-5$ & 3.70 & 1.080 \\
5 & Valuation of Property, Plants \& Equipment & $1-5$ & 3.64 & 1.070 \\
6 & Valuation of Land \& Building & $1-5$ & 3.58 & 1.175 \\
7 & Valuation of Pension Liabilities & $1-5$ & 3.42 & 1.200 \\
8 & Valuation of Goodwill \& Intangibles in Business Combination & $1-5$ & 3.26 & 1.235 \\
9 & Valuation of Share-Based Payments & $1-5$ & 3.14 & 1.201 \\
10 & Valuation of Endowment Funds & $1-5$ & 2.83 & 1.201 \\
& Cluster Mean [for all 10 items] & 3.49 & \\
& ANOVA p value (based on length of experience) [for 9 items, excluding bio- & .495 & \\
& logical assets] F ratio ( p value) & $(.739)$ & \\
& ANOVA p value (based on length of experience of auditors specialising in agric.) [ for bio- & 1.124 \\
& logical assets] F ratio ( p value) & & $(.375)$ \\
\hline
\end{tabular}

\footnotetext{
*Analysis based on response supplied by 17 auditors specialising in audit of agric./agro-allied firms, as biological assets are peculiar to firms in the agriculture sector
} 
From Table 3, application of fair value measurement in investment property valuation has the highest-ranking $(\mathrm{M}=3.83, \mathrm{SD}=1.016)$, followed by valuation of financial assets $(\mathrm{M}=$ 3.74), biological assets $(M=3.71, S D=1.213)$, financial liabilities $(M=3.70, S D=1.080)$, property, plants \& equipment $(\mathrm{M}=3.64, \mathrm{SD}=1.070)$, and land $\&$ building $(\mathrm{M}=3.58, \mathrm{SD}=$ 1.175). Each of these six items has a Mean score above 3.0, meaning moderate application rate in these areas. However, reckoning that IFRS 13 was contextually developed to value financial assets and financial liabilities, it may not be surprising that these items are among the highest-ranking items. Tangible assets (such as investment property; property, plants \& equipment; and land \& building), biological assets (animals \& plants), and other categories of assets and liabilities [pension liabilities $(M=3.42)$, goodwill \& intangibles in business combination $(M=3.26)$, and share-based payments $(M=3.14)]$ all witnessed moderate application level with Mean score above 3.00. Considering the lowest ranking Mean of 2.83, it is deduced that fair value measurement is barely applied in the valuation of endowment funds.

In sum, while tangible assets have higher application rate in comparison to some intangible items (such as pension liabilities, goodwill \& intangibles acquired in business combination, share-based payments, and endowment funds), financial assets and financial liabilities are the two highest-ranking items among intangibles recording a moderate level of application. With a cluster Mean of 3.49 on a 5-point calibrated scale (equivalent to $69.8 \%$ ) for the ten items in Table 3, the extent of application of fair value measurement by reporting entities in Nigeria is considered moderate. One-way ANOVA $p$ value indicates no significant difference in the opinion of auditors (excluding biological assets, as this category of asset is peculiar to the agriculture/ agro-allied sector) based on their work experiences $(p=.739>.05)$. Oneway ANOVA $p$ value also confirms no significant difference in the extent of application to biological assets in agriculture/agro-allied sector $(p=.375>.05)$.

Result from analysis carried out on the extent of application of fair value measurement across sectors is presented in Table 4. 
Table 4

Areas of Application of FVA Across Sectors of Reporting Entities

\begin{tabular}{|c|c|c|c|c|c|}
\hline Area of Application & Sector & $\mathrm{N}$ & Mean & Std. Deviation & $\begin{array}{l}\text { ANOVA } \\
\text { p value* }\end{array}$ \\
\hline \multirow{10}{*}{$\begin{array}{l}\text { Valuation of Finan- } \\
\text { cial Assets } \\
\text { (e.g. bonds, trea- } \\
\text { sury bills, equity, } \\
\text { etc.) }\end{array}$} & Manufacturing & 50 & 3.58 & 1.052 & \multirow{10}{*}{.001} \\
\hline & Financial Service & 54 & 4.31 & .886 & \\
\hline & $\begin{array}{l}\text { Technology, Media \& Tele- } \\
\text { com. }\end{array}$ & 52 & 3.56 & 1.110 & \\
\hline & Oil \& Gas & 45 & 3.71 & .920 & \\
\hline & SMEs & 35 & 3.60 & 1.143 & \\
\hline & Energy & 24 & 3.42 & 1.100 & \\
\hline & Agriculture./Agro-allied & 17 & 3.71 & 1.047 & \\
\hline & Total & 277 & 3.74 & 1.059 & \\
\hline & Manufacturing & 50 & 3.64 & 1.064 & \\
\hline & Financial Service & 54 & 4.09 & 1.069 & \\
\hline \multirow{9}{*}{$\begin{array}{l}\text { Valuation of Finan- } \\
\text { cial Liabilities (e.g. } \\
\text { bonds, treasury } \\
\text { bills, shares, loan \& } \\
\text { borrowings, etc.) }\end{array}$} & $\begin{array}{l}\text { Technology, Media \& Tele- } \\
\text { com. }\end{array}$ & 52 & 3.44 & 1.056 & \multirow[t]{8}{*}{.009} \\
\hline & Oil \& Gas & 45 & 3.76 & 1.004 & \\
\hline & SMEs & 35 & 3.31 & 1.157 & \\
\hline & Energy & 24 & 4.00 & 1.063 & \\
\hline & Agriculture./Agro-allied & 17 & 3.71 & .920 & \\
\hline & Total & 277 & 3.70 & 1.080 & \\
\hline & Manufacturing & 50 & 3.44 & 1.232 & \\
\hline & Financial Service & 54 & 3.50 & 1.424 & \\
\hline & $\begin{array}{l}\text { Technology, Media \& Tele- } \\
\text { com. }\end{array}$ & 52 & 3.25 & 1.281 & \multirow[t]{6}{*}{.847} \\
\hline \multirow{5}{*}{$\begin{array}{l}\text { Valuation of Pen- } \\
\text { sion Liabilities }\end{array}$} & Oil \& Gas & 45 & 3.51 & .968 & \\
\hline & SMEs & 35 & 3.31 & 1.051 & \\
\hline & Energy & 24 & 3.63 & .924 & \\
\hline & Agriculture./Agro-allied & 17 & 3.29 & 1.359 & \\
\hline & Total & 277 & 3.42 & 1.200 & \\
\hline
\end{tabular}


Valuation of Goodwill \& Intangibles acquired in Business Combination

Valuation of Endowment Funds

Valuation of ShareBased Payments

Valuation of Property, Plants \& Equipment
Manufacturing

Financial Service

Technology, Media \& Telecom.

Oil \& Gas

SMEs

Energy

Agriculture./Agro-allied

Total

Manufacturing

Financial Service

Technology, Media \& Telecom.

Oil \& Gas

SMEs

Energy

Agriculture./Agro-allied

Total

Manufacturing

Financial Service

Technology, Media \& Telecom.

Oil \& Gas

SMEs

Energy

Agriculture./Agro-allied

Total

Manufacturing

Financial Service

Technology, Media \& Telecom.

Oil \& Gas

SMEs

Energy

Agriculture./Agro-allied

Total

$\begin{array}{ccc}50 & 3.12 & 1.394 \\ 54 & 3.67 & 1.289 \\ 52 & 3.21 & 1.160 \\ 45 & 3.29 & 1.079 \\ 35 & 2.89 & 1.078 \\ 24 & 3.46 & 1.285 \\ 17 & 2.94 & 1.197 \\ 277 & 3.26 & 1.235 \\ 50 & 2.82 & 1.351 \\ 54 & 2.80 & 1.406\end{array}$

52

2.88

1.166

.993

$\begin{array}{lll}45 & 2.91 \quad .925\end{array}$

35

2.74

1.094

24

2.75

1.032

$17 \quad 2.94$

1.391

277

2.83

1.201

$50 \quad 3.02$

1.317

$54 \quad 3.31$

1.385

$52 \quad 3.06$

1.127

.105

$45 \quad 3.47$

.815

35

2.71

1.202

24

3.33

1.167

$17 \quad 3.00$

1.173

$277 \quad 3.14$

1.201

50

3.70

.931

54

3.76

1.098

52

3.44

1.145

.319

45

3.49

1.079

35

3.57

1.065

24

4.04

.806

17

3.65

1.367

277

3.64

1.070

.071 


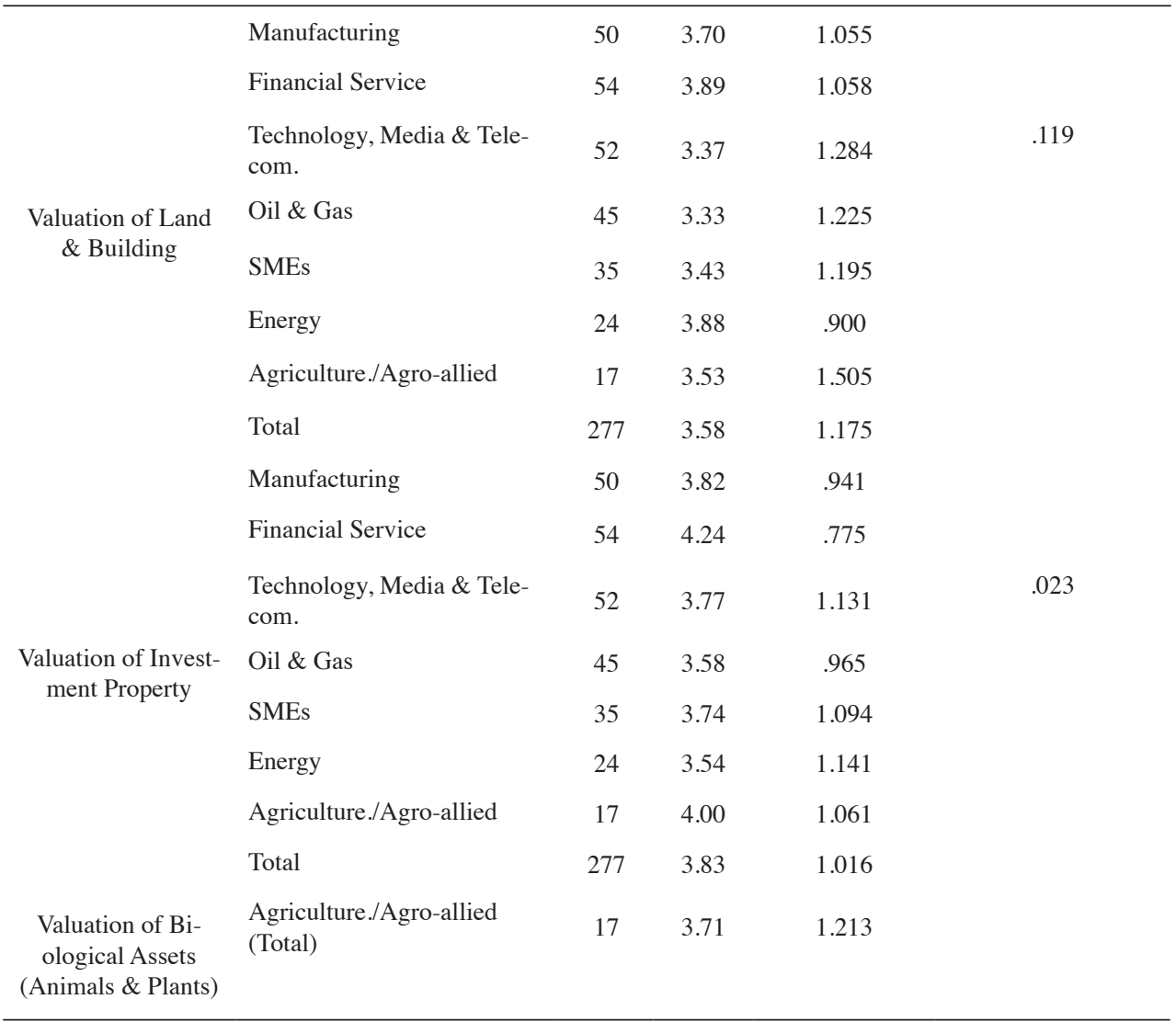

*ANOVA $p$ value based on Sector of Reporting Entities

Application in the valuation of financial assets in the financial service sector has the highest rating $(\mathrm{M}=4.31)$ and the consensus among respondents is strong in this regard (lowest dispersion (SD) of .886 in all the seven sectors) [Table 4]. This is followed closely by both the Oil \& Gas $(\mathrm{M}=3.71, \mathrm{SD}=.921)$ and Agriculture /Agro-allied $(\mathrm{M}=3.71, \mathrm{SD}=1.047)$ sectors, but with stronger consensus among auditors in the oil \& gas sector (i.e. lower SD of 921). High level of application for reporting entities in the oil \& gas sector may be because firms operating in this sector carry significant amount of financial assets (bonds, treasury bills, equity) and financial liabilities (bonds, treasury bills, shares, loan \& borrowings) to finance their capital-intensive operations. Manufacturing firms $(M=3.58)$ and Technology, Media \& Telecommunication firms $(M=3.56)$ have moderate application rate, with Mean scores above 3.50. The Energy sector $(M=3.42)$ has a moderate ranking in the extent of application. The 
application rate with respect to financial assets is moderate for firms in financial service, Oil \& Gas, SMEs, Agriculture /Agro-allied, Manufacturing sectors and the Energy sector. The overall Mean score of 3.74 establishes that fair value estimate is moderately applied in the valuation of financial assets, but the extent of application significantly differs across sectors $(p=.001<.05)$.

In the valuation of financial liabilities, the financial service sector recorded the highest application rate $(M=4.09)$, followed by the Energy $(M=4.00)$, Oil \& Gas $(M=3.76)$, Agriculture /Agro-allied $(\mathrm{M}=3.71)$, and Manufacturing $(\mathrm{M}=3.64)$ sectors. The SMEs sector has the lowest rating $(M=3.31)$. In sum, the extent of application of fair value measurement in financial liabilities valuation is significantly different among reporting entities $(p=.009<$ .05). Extent of application in valuation of pension liabilities fluctuates between 3.25 to 3.63 , yielding an overall Mean of 3.42, indicating a moderate level of application. Inferential statistics confirms that there is no significant difference in the extent of application in this area $(p$ $=.847>.05)$. For the valuation of goodwill \& intangibles acquired in business combination, the variation in application level is not so marked, as Mean score is between 2.89 and 3.67. Except for the Agriculture /Agro-allied sector $(\mathrm{M}=2.94)$ and SMEs $(\mathrm{M}=2.89)$ that have the lowest scores, the scores for the other sectors are quite close (Mean scores from 3.67 to 3.12). The difference in scores among firms in this respect is not much, but is significant at $10 \%(p=.071<.10)$. With an overall Mean score of 3.26 , extent of application in valuation of goodwill \& intangibles acquired in business combination is considered moderate.

Application in the valuation of endowment funds has the lowest range of values (Mean of 2.74 to 2.94), and an overall Mean score of 2.83. The extent of application, considered low, does not evince statistical significance $(p=.993>.05)$. The range of scores for valuation of share-based payments also fluctuated around 3.00 and 3.47, except for SMEs with Mean of 2.71. This is corroborated by the observation that the difference in score is not statistically significant $(p=.105)$. With an overall Mean of 3.14, the extent of application is considered moderate.

The rating for the valuation of property, plants \& equipment across sectors generally assumed high value (Mean of 3.44 to 4.04) in comparison to some other items such as endowment fund, pension liabilities, and goodwill. The Energy sector recorded the highest Mean of 4.04 (and the lowest dispersion, $\mathrm{SD}=.806$ ), which is noticeably higher than the next-ranking sector - the Financial Service - with a Mean of 3.76 (SD =1.098). The Manufacturing sector, ranking next to Financial Service Sector, also has a Mean of 3.70 (SD = .931). As the Energy sector should be heavily-invested in property, plants \& equipment, it may be expected that reporting entities in this sector would apply fair value estimates to some reasonable extent. The emergence of Financial Service as one of the sectors with high application level could be attribute to the ubiquitousness of financial institutions in Nigeria; banks generally have 
wide branch network and may understandably apply fair value measurement extensively to property, plants \& equipment. With an overall Mean of 3.64, the extent of application to property, plant \& equipment is considered moderate. The distribution of Mean scores for valuation of land \& building follows a similar pattern to property, plants \& equipment, with the Financial Service $(M=3.89)$, Energy, $(M=3.70)$ and Manufacturing $(M=3.70)$ sectors taking the lead. Seeing that property, plants \& equipment, and Land \& Building are both tangible assets, Financial institutions may have more land \& buildings in comparison to Energy firms and Manufacturing concerns possibly because of the wide branch networks typical of commercial banks. The Manufacturing sector, being the third-ranking in application level to land \& building, would usually invest in large expanse of land and spacious buildings to commence and carry on production runs.

In investment property valuation, financial service firms have the highest-ranking Mean of 4.24, followed by Agriculture/Agro-allied $(\mathrm{M}=4.00)$, and Manufacturing $(\mathrm{M}=3.82)$ firms. The Energy sector ranks lowest $(\mathrm{M}=3.54)$. With an overall Mean of 3.83, it is concluded that the application level in investment property valuation is moderate.

\section{Fair value measurement valuation methods adopted by reporting entities}

Table 5 contains result on valuation methods used in estimating fair value of assets and liabilities.

For the valuation of financial assets, the market value approach is the most applied (81.9\%), followed by the cost approach (10.1\%) [Table 5]. The application rate of other methods is negligible (all adding up to $8 \%$ ). The market value approach has the highest application level under financial assets probably because it is easier to obtain the market price of similar financial assets than to apply other complex methods such as income- or expert- approach. For example, the market price of bonds and equities can be easily obtained from an active Stock Exchange. Unquoted investments with no market value may be estimated using the amounts that would be currently required to replace a similar financial asset - this explains the $10.1 \%$ application rate under the cost approach. The valuation of financial liabilities applies the market approach $73.6 \%$, and cost approach $10.5 \%$, following a similar usage pattern for financial assets, while the application of other methods assumed low rates (summing up to $15.9 \%$ ). The combined usage rate of the market and cost approaches is $84.1 \%$, thus reiterating the result observed for valuation of financial assets that market and cost approaches are the dominant methods used in the valuation of financial instruments. 
Table 5

Valuation Methods in use for FV Measurement by Reporting Entities in Nigeria

\begin{tabular}{|c|c|c|c|c|c|c|c|}
\hline $\mathrm{S} / \mathrm{N}$ & ITEM & MV & $\mathrm{CV}$ & IV & EX & NA & Total \\
\hline 1 & Financial Assets & $\begin{array}{c}227 \\
(81.9 \%)\end{array}$ & $\begin{array}{c}28 \\
(10.1 \%)\end{array}$ & $\begin{array}{c}14 \\
(5.1 \%)\end{array}$ & $\begin{array}{c}6 \\
(2.2 \%)\end{array}$ & $\begin{array}{c}2 \\
(0.7 \%)\end{array}$ & $\begin{array}{c}277 \\
(100 \%)\end{array}$ \\
\hline 2 & Financial Liabilities & $\begin{array}{c}204 \\
(73.6 \%)\end{array}$ & $\begin{array}{c}29 \\
(10.5 \%)\end{array}$ & $\begin{array}{c}25 \\
(9.0 \%)\end{array}$ & $\begin{array}{c}8 \\
(2.9 \%)\end{array}$ & $\begin{array}{c}11 \\
(4.0 \%)\end{array}$ & $\begin{array}{c}277 \\
(100 \%)\end{array}$ \\
\hline 3 & Pension Liabilities & $\begin{array}{c}39 \\
(14.1 \%)\end{array}$ & $\begin{array}{c}50 \\
(18.1 \%)\end{array}$ & $\begin{array}{c}28 \\
(10.1 \%)\end{array}$ & $\begin{array}{c}114 \\
(41.2 \%)\end{array}$ & $\begin{array}{c}46 \\
(16.6 \%)\end{array}$ & $\begin{array}{c}277 \\
(100 \%)\end{array}$ \\
\hline 4 & $\begin{array}{l}\text { Goodwill \& Intan- } \\
\text { gibles in Business } \\
\text { Combination }\end{array}$ & $\begin{array}{c}73 \\
(26.4 \%)\end{array}$ & $\begin{array}{c}44 \\
(15.9 \%)\end{array}$ & $\begin{array}{c}61 \\
(22.0 \%)\end{array}$ & $\begin{array}{c}60 \\
(21.7 \%)\end{array}$ & $\begin{array}{c}39 \\
(14.1 \%)\end{array}$ & $\begin{array}{c}277 \\
(100 \%)\end{array}$ \\
\hline 5 & Endowment Funds & $\begin{array}{c}52 \\
(18.8 \%)\end{array}$ & $\begin{array}{c}22 \\
(7.9 \%)\end{array}$ & $\begin{array}{c}39 \\
(14.1 \%)\end{array}$ & $\begin{array}{c}74 \\
(26.7 \%)\end{array}$ & $\begin{array}{c}90 \\
(32.5 \%)\end{array}$ & $\begin{array}{c}277 \\
(100 \%)\end{array}$ \\
\hline 6 & Share-based Payments & $\begin{array}{c}100 \\
(36.1 \%)\end{array}$ & $\begin{array}{c}17 \\
(6.1 \%)\end{array}$ & $\begin{array}{c}43 \\
(15.5 \%)\end{array}$ & $\begin{array}{c}55 \\
(19.9 \%)\end{array}$ & $\begin{array}{c}62 \\
(22.4 \%)\end{array}$ & $\begin{array}{c}277 \\
(100 \%)\end{array}$ \\
\hline 7 & $\begin{array}{l}\text { Property, Plants \& } \\
\text { Equipment }\end{array}$ & $\begin{array}{c}75 \\
(27.1 \%)\end{array}$ & $\begin{array}{c}108 \\
(39.0 \%)\end{array}$ & $\begin{array}{c}17 \\
(6.1 \%)\end{array}$ & $\begin{array}{c}64 \\
(23.1 \%)\end{array}$ & $\begin{array}{c}13 \\
(4.7 \%)\end{array}$ & $\begin{array}{c}277 \\
(100 \%)\end{array}$ \\
\hline 8 & Land \& Building & $\begin{array}{c}79 \\
(28.5 \%)\end{array}$ & $\begin{array}{c}88 \\
(31.8 \%)\end{array}$ & $\begin{array}{c}22 \\
(7.9 \%)\end{array}$ & $\begin{array}{c}80 \\
(28.9 \%)\end{array}$ & $\begin{array}{c}8 \\
(2.9 \%)\end{array}$ & $\begin{array}{c}277 \\
(100 \%)\end{array}$ \\
\hline 9 & Investment Property & $\begin{array}{c}95 \\
(34.3 \%)\end{array}$ & $\begin{array}{c}56 \\
(20.2 \%)\end{array}$ & $\begin{array}{c}21 \\
(7.6 \%)\end{array}$ & $\begin{array}{c}94 \\
(33.9 \%)\end{array}$ & $\begin{array}{c}11 \\
(4.0 \%)\end{array}$ & $\begin{array}{c}277 \\
(100 \%)\end{array}$ \\
\hline 10 & $\begin{array}{l}\text { Biological Assets } \\
\text { (Animals \& Plants) }\end{array}$ & $\begin{array}{c}4 \\
(23.5 \%)\end{array}$ & $\begin{array}{c}4 \\
(23.5 \%)\end{array}$ & $\begin{array}{c}2 \\
(11.8 \%)\end{array}$ & $\begin{array}{c}4 \\
(23.5 \%)\end{array}$ & $\begin{array}{c}3 \\
(17.6 \%)\end{array}$ & $\begin{array}{c}277 \\
(100 \%)\end{array}$ \\
\hline & $\begin{array}{l}\text { verage usage rate of } \\
\text { valuation method }\end{array}$ & $36.4 \%$ & $18.3 \%$ & $10.9 \%$ & $22.4 \%$ & $12.0 \%$ & $100.0 \%$ \\
\hline
\end{tabular}

"Based on analysis of response provided by auditors specialising in Agriculture/ Agro-allied sector

For pension liabilities, the dominant valuation method shifted to estimation by valuation experts $(41.2 \%)$, followed by the cost approach $(18.1 \%)$, and the market value approach (14.1\%). An average financial accountant/auditor may not have the competence to estimate the value of pension liabilities due to the technicalities involved in such valuation, and the option left may be to rely on the figures provided by valuation experts. If some preparers of financial reports do not want to resort to valuations furnished by experts, they may use the amount required to replace the liability (cost approach) or seek to estimate the market price of a similar liability (market value approach). The market approach recorded a $14.1 \%$ application rate because it may be difficult to obtain the market price of pension liabilities. 
The income approach has the lowest rate of utilisation $(10.1 \%)$ because such a technique requires the valuation of cash flows which may be difficult to obtain. $16.6 \%$ of the cases are not classified into any of the four methods - this represents a grey area in the application of fair value measurement in Nigeria.

The application rate of methods for the valuation of goodwill \& other intangibles acquired in business combination is somewhat spread, but market approach witnessed the highest usage rate of $26.4 \%$, compared to the income (22.0\%), expert valuation $(21.7 \%)$, and cost (15.9\%) approaches. It is common practice to report fair value of assets and liabilities appearing in the books of the acquiring (parent company) and acquired (subsidiary) entities at the acquisition date, resulting in the computation of purchased goodwill (the excess of the purchase consideration over the net assets acquired). Such procedures are popular with the market value and cost approaches - both methods combine to make $48.4 \%$, while the combination of expert valuation and cost approaches account for $37.6 \%$. $14.1 \%$ of the cases are left unclassified, reflecting some greyness in this area as well.

Endowments funds are mostly valued using expert valuation approach (26.7\%) perhaps because in-house experts that could use cost or income valuation approaches are lacking in reporting entities, or there is non-availability of open market price for this item as to promote the use of market value approach. $32.5 \%$ of the cases are left uncategorised into any of the valuation methods. Share-based payments are mostly valued using market approach $(36.1 \%)$ understandably because the market prices of financial instruments are available from Stock Exchange price-quotation. $22.4 \%$ of the cases are unclassified (representing the second highest incidence of uncategorised cases after endowment funds), corroborating the low ranking of share-based payments (ranked $9^{\text {th }}$ out of 10) in Table 3.

Property, plants \& equipment are predominantly valued using the cost approach $(39.0 \%)$ and the market approach (27.1\%). Both approaches jointly account for $66.1 \%$ usage rate. The expert valuation method is applied $23.1 \%$. The predominance of both the cost and market approaches may not be surprising because tangible assets like property, plants \& equipment are subjected to market-price testing and replacement-cost assessment from time to time. As for the expert valuation method, it is also a popular practice to have estate-valuers provide estimates (open market value and forced sale value) for items of property, plants \& equipment. The low rate of $4.7 \%$ for unclassified cases (Table 5) reiterates the moderate level of application of fair value estimates in the valuation of property, plant \& equipment reported in Table 3 .

The distribution of the usage rate of methods in the valuation of land \& building, and investment property follows a pattern similar to property, plants \& equipment in which the valuation methods are market-, cost- and expert valuation- approach. In the case of land \& building, the three methods mostly used are: cost (31.8\%), expert valuation (28.9\%), and market $(28.5 \%)$ approaches, with $2.9 \%$ unclassified cases. For valuation of investment property, 
the application rate of methods is in descending order of: market- (34.3\%), expert valuation$(33.9 \%)$ and cost- (20.2\%) approach, while $4.0 \%$ of the cases are unclassified. Biological assets are valued using three dominant methods - market value $(23.5 \%)$, cost $(23.5 \%)$ and expert valuation $(23.5 \%)$ - which rank equally.

To recapitulate, the number of unclassified cases for the valuation of property, plants \& equipment, land $\&$ building, and investment property is low. This contrasts sharply with the high number under valuation of intangible assets and liabilities (except financial assets and liabilities) in which respondents were unable to ascribe valuation methods to items. This result underscores the observation that fair value measurement is applied more to tangible assets than intangible assets/liabilities. The observation that financial assets and financial liabilities have the least incidence of unclassified cases among intangible items only reinforces the submission that the level of application for financial instruments is higher than others. However, the unclassified cases for valuation methods reveal some grey areas in the application of fair value accounting in Nigeria, especially in connection with the valuation of intangible items.

In summary, the overall usage rate of valuation methods is in the descending order of: market approach (36.4\%), expert estimation approach $(22.4 \%)$, cost approach (18.3\%), and income approach $(10.9 \%)$ respectively.

\section{Test of hypotheses}

Drawing from the results reported in Table 3, the ANOVA $p$ value indicates that there is no significant difference in the perception of respondents on the extent of application of fair value measurement in nine areas (with the exclusion of biological assets) $(p=.739>.05)$. Also, there is no significant difference in level of application to biological assets valuation $(p=.375$ $>$.05). These results establish that there is a consensus among respondents on the moderate application level of fair value accounting by reporting entities in Nigeria. H1 is therefore rejected and it is concluded that there is no significant difference in the overall extent of application of fair value accounting by reporting entities in Nigeria based on auditors' perception.

Result in Table 4 reveals that there is significant difference at 5\% in the application level of fair value measurement across sectors in the valuation of financial assets $(p=.001<.05)$, financial liabilities $(p=.009<.05)$, investment property $(p=.023<.05)$, and a significant difference at $10 \%$ in the valuation of goodwill \& intangibles acquired in business combination $(p=.071<.10)$. The result also reveals no statistically significant difference in extent of application in the valuation of pension liabilities $(p=.847>.05)$, endowment funds $(p=$ $.993>.05)$, share-based payments $(p=.105>.05)$, property, plants \& equipment $(p=.319>$ $.05)$, and land \& building ( $p=.119>.05)$ among reporting entities. Considering that there is significant difference in application level across sectors in four (4) out of the ten (10) areas 
examined, $\mathrm{H} 2$ is retained, and it is concluded that the application level of fair value measurement for accounting items significantly differ across sectors of reporting entities in Nigeria based on auditors' perception.

\section{Discussion}

Notwithstanding that the application of IFRS 13 is not mandatory but is at the instance of reporting entities to decide the classes of assets and liabilities to be fair-valued, it was observed that the extent of application of fair value measurement by reporting entities in Nigeria is moderate (Table 3). A plausible reason for this could be that firms may have benefitted from the application of fair value measurement in enhancing the quality of accounting information as suggested in literature (e.g. Ting \& Soo, 2005; Volha, 2010; Okafor \& Ogiedu, 2012; Enahoro \& Jayeoba, 2013).

With respect to the application of fair value measurement to the valuation of financial assets and financial liabilities (Table 4), the emergence of the financial services as the sector with the highest application level may have been anticipated. This is because financial institutions will inherently carry financial instruments as part of their operations in performing financial intermediation role. Meanwhile, fair value measurement was originally developed for valuing financial instruments (Hague, 2002; Yichao, 2010). Financial institutions may hold more financial instruments than other organisations, and may extensively apply fair value accounting in this area than others. Studies have shown that the largest users of fair value accounting are essentially financial service companies (e.g. Cardao-Pito \& Barros, 2016). As there were no local SASs covering fair value estimates in Nigeria, financial institutions may be familiar with erstwhile international accounting standards on fair value measurement as to be well advanced in their application in comparison to reporting entities in other sectors that commenced application of fair value accounting consequent on the adoption of IFRS by listed companies in 2012 and the subsequent launching of IFRS 13 in January 2013. The appearance of the oil \& gas sector among the top-three sectors applying fair value estimates in the valuation of financial assets and financial liabilities could be attributable to carrying high volumes and values of financial instruments in their books because of the capital-intensive nature of transactions in the sector. Manufacturing, Technology, Media \& Telecommunication, and Energy firms may not carry as much financial instruments in their books as financial institutions and oil \& gas firms as to warrant the extensive application of fair value measurement to these items. 
Small and Medium Scale Enterprises (SMEs) registered a high level of application in investment property $(M=3.74)$, financial assets $(M=3.60)$, and property, plants \& equipment $(\mathrm{M}=3.57)$; moderate level of application in land \& building $(\mathrm{M}=3.43)$, financial liabilities $(\mathrm{M}=3.31)$, and pension liabilities $(\mathrm{M}=3.31)$; and low level of application in valuation of goodwill \& intangibles acquired in business combination $(M=2.89)$, endowment funds ( $M$ $=2.74)$, and share-based payments $(M=2.71)$ [Table 4]. Application level in these areas is generally between 2.71 to 3.74 for SMEs, which is somewhat commendable as it compares well with the rating of other sectors. SMEs reported low Mean score in areas where other sectors scored low as well (for example, low score was generally observed for pension liabilities and endowment funds across sectors). This implies that some areas in the application of fair value estimates are grey to reporting entities in Nigeria, whatever their size or sector.

Extent of application in valuation of pension liabilities, endowment funds, and share-based payments appears to be moderate, and does not significantly differ among reporting entities (Table 4).Also, application level for these items is low in comparison to others such as financial assets; financial liabilities; property, plants \& equipment; land \& building; and investment property, meaning these areas of application need improvement.

A close examination of the result in Table 4 reveals that the level of investment in an asset/ liability determines the application rate of fair value measurement to the concerned asset/ liability. While high level of investment in an asset/ a liability appears to prompt extensive application, low investment level correspondingly leads to negligible usage rate. For example, while Financial Institutions ranked highest in the application of fair value measurement to financial instruments (as it would be expected that they invest in this category because of the nature of their business), the Energy sector ranked highest in the valuation of property, plants \& equipment. The level of property, plants \& equipment owned by firms operating in the Energy sector may be expectedly higher than those of Financial Institutions. Conversely, it would be expected that Financial Service firms carry higher level of financial instruments than Energy firms.

The observation that endowment fund has the lowest level of application $(\mathrm{M}=2.83)$ [Table 3 ] and the highest magnitude of unclassified cases (32.5\%) for valuation methods (Table 5) establish that the level of awareness on fair value measurement in this area is low and requires attention of concerned stakeholders. The low application rate for the income approach (Table 5 ) is also noteworthy for research and practice in fair value measurement. The penchant for the use of expert valuation method leaves fair value estimates vulnerable to manipulations by management as noted in literature (e.g. Watts, 2006; Landsman, 2007; Danbolt \& Rees, 2008; Bessong \& Charles, 2012) because unscrupulous managers could collude with valuers. Such loopholes could be opportunistically exploited by fraudulent or compromising valuation experts. This increase audit risks associated with fair value measurement and underscores the 
need for accountants and auditors to develop competence in valuation of assets/liabilities or put mechanisms in place to verify reported values.

Low usage of cost and income methods could be due to lack of information. Empirical studies reveal that the challenges of applying FV measurement in both developed and developing countries bother on lack of information for valuation (e.g. Glover, Taylor, \& Wu, 2016; Barker \& Schulte, 2017) which promotes the use of proprietary models and significant complex calculations (Griffith, Hammersley \& Kadous, 2015), leading to high subjectivity and estimation uncertainty (Cannon \& Bedard, 2017), and tendency for manipulation of earnings (Procházka, 2011; Abdullatif, 2016). Lack of institutional structures to support valuation is also contributory to the low uptake of such valuation methods (Kumarasiri \& Fisher, 2011; Barker \& Schulte, 2017). A number of studies from scholars such as Barth (1994), Petroni \& Wahlen (1995), Nelson (1996) and, Botosan, Beatty, Hopkins, Nelson \& Venkatachalam (2005), among others, claim that fair values obtained from more organised, active markets such as share prices from Stock Exchanges are more credible and reliable than those obtained from less active markets and various internal evaluation models of entities. Their submission buttresses the criticalness of institutional structures supporting fair value measurement. The negligible usage rate of the cost and income methods may also not be unconnected to the difficulty of applying them owing to knowledge gap. Glover, Taylor \& Wu's (2014) and Oyewo's (2020) study show that lack of verifiable and corroborative evidence, and limited knowledge and expertise regarding complex valuation inputs, analyses and models are challenges confronting preparers and auditors of fair value measurements. Appah (2018), Klibi (2016) and Abdullatif (2016) submit that knowledge gap among concerned stakeholders (i.e. regulators, preparers, and auditors) is one of the major challenges of applying fair value measurement.

To minimise subjectivity in fair value measurement, other standards aside IFRS 13 may have to be relied upon. Whereas IFRS 13 prescribes how firms should calculate fair value when they need to do so, reporting entities would have to apply other standards relevant to fair value measurement, particularly for items that IFRS 13 does not sufficiently cover. This is because measurements and disclosures that are based on fair value, such as fair value less costs to sell, are within the scope of IFRS 13. For instance, agriculture firms can combine IAS 41 on biological assets with IFRS 13, as IAS 41 is expected to satisfactorily address the peculiarities of biological assets and agricultural produce. Also, IAS 2 can be used to compliment IFRS 13 by commodity broker-traders. The pricing and evaluation services of experts can also be used to promote the application of the other non-market-based methods, especially the cost and income approaches (Hux, 2017; Joe, Vandervelde \& Wu, 2017; Emett, Libby \& Nelson, 2018; International Standard on Auditing, ISA 540, 2018).

The observation that the market approach is the most applied method on one hand, and the predominant method for valuation of financial assets, liabilities, and share-based payments 
on the other hand (Table 5) underscores the critical role that institutional structures play in fostering the application of fair value accounting (Barker \& Schulte, 2017; Cannon \& Bedard, 2017; Glover et al., 2016). The crucialness of an efficient capital market in impelling the diffusion of fair value accounting has been noted by scholars (e.g. Pacter, 2007; Mwape, 2010; Enahoro \& Jayeoba, 2013; Ijeoma, 2014; Jayeoba \& Ajibade, 2016). This implies that the efficiency of the capital market in impounding new information in the valuation of assets and liabilities contributes to the successful application of fair value measurement.

\section{Conclusion}

This study investigates the diffusion of fair value accounting in the Nigerian context, based on the perception of external auditors as one of the important stakeholder-groups concerned with the quality of accounting information. The study specifically examined the extent of application of fair value measurement, and the valuation methods used in estimating fair value of assets and liabilities by reporting entities in Nigeria.

Result shows that the extent of application of fair value measurement by reporting entities is moderate (research objective one). There is significant difference across sectors in the extent of application of fair value measurement in the valuation of financial assets, financial liabilities, investment property, and goodwill \& intangibles acquired in business combination, but no significant difference in the valuation of pension liabilities, endowment funds, share-based payments, property, plants \& equipment, and land \& building. While tangible assets witnessed higher application rate in comparison to some intangibles (such as pension liabilities, goodwill \& intangibles acquired in business combination, share-based payments, and endowment funds), financial assets and financial liabilities recorded the highest application rate. The observation that SMEs apply fair value measurement to a reasonable extent confirms the appreciable diffusion rate of fair value accounting in Nigeria - the result that fair value measurement is applied to a moderate level in the valuation of biological assets in the Agriculture /Agro-allied sector buttresses this submission. The moderate level of application of fair value measurement as an innovation by reporting entities in Nigeria may not be unconnected to the relative advantage of its adoption over historical cost in the way of enhancing the qualitative characteristics of accounting information as posited in the diffusion of innovation theory invoked by this study.

The application rate of valuation methods by reporting entities are in the descending order of; market approach, expert estimation method, cost approach and income approach with average usage rates of $36.4 \%, 22.4 \%, 18.3 \%$ and $10.9 \%$ respectively (research objective two). It appears the market and cost approaches are applied more extensively in the valuation 
of tangible assets. The market approach is preferred in the valuation of financial instruments (financial assets and liabilities), while the expert estimation method is more applicable to the valuation of intangible assets and intangible liabilities (except financial instruments).

The study contributes to knowledge in that it is one of the few investigations conducted on fair value measurement in the Nigerian context post-IFRS 13 adoption. Studies on fair value measurement covering subthemes such as prospects and challenges of fair value application, impact of fair value measurement on reported profit, amongst others, still leave much to be desired, as post-implementation issues surrounding level of application of fair value measurement and valuation methods used by reporting entities in Nigeria are yet to be rigorously investigated. The current study closes some gaps in this regard.

Considering that the capital market is critical to the supply of information for gauging fair value estimates, this study calls on regulators to ensure financial instruments quoted on the stock exchange are reliably priced. Institutional apparatus that will facilitate the reliable pricing of non-financial assets and non-financial liabilities should also be emplaced by relevant authorities. Concerned stakeholders such as accounting academics, professional accounting bodies, and the Financial Reporting Council of Nigeria (FRC) can also promote the diffusion of fair value measurement through public enlightenments, workshops, symposia, and trainings, considering that it is relatively new concept in the Nigerian environment. Inculcation of fair value accounting in the curriculums of academic and professional accounting programmes should also be undertaken to bridge knowledge gap.

The results from this study should be applied with caution owing to some limitations surrounding the scope of coverage, data collection method and research paradigm adopted. Acknowledging that not all sectors are represented in this study, future studies may examine the perception of auditors specialising in other sectors. For instance, analysis for agriculture/ agro-allied sector was restricted to data gathered from fifteen respondents specialising in the audit of agriculture business. Scope of coverage can be extended by taking more samples from the sector to validate results. Sector-specific studies on the application level of fair value measurement can also be carried out. Studies investigating valuation methods applied to ascertain the fair value of assets and liabilities could be investigated by content-analysing disclosures on fair value measurement in annual reports. The study adopted a positivist research paradigm and a quantitative research design; future studies may consider using a qualitative or a mixed research design, whereby data collection through questionnaire is complemented by interview. Other studies may also increase the sample size across sectors to improve generalisability of results. 


\section{B. Oyewo / Contaduría y Administración 66(2) 2021, 1-33 \\ http://dx.doi.org/10.22201/fca.24488410e.2021.2178}

\section{References}

Abdullatif, M. (2016). Auditing fair value estimates in developing countries: The case of Jordan. Asian Journal of Business and Accounting, 9(2), 102-140.

Adams, S. \& Simnett, R. (2011). Integrated reporting: An opportunity for Australia's not-for profit sector. Australian Accounting Review, 21 (3), 292 - 301. https://doi.org/10.1111/j.1835-2561.2011.00143.x

Ahmed, K. (2012). Auditing fair value measurements and disclosures: A case of the Big 4 audit firms. Unpublished Master's Thesis in Business Administration, Umeå School of Business, Umeå University, Sweden. Available in http://www.diva-portal.org/smash/get/diva2:611984/fulltext01.pdf (consulted 17/08/2017)

Akinsulire, O. (2010). Financial management. Lagos Ceemol Nigeria Limited.

Antunes, T., \& Alves, A. (2008). The adequacy of the Enterprise Resources Planning (ERP) Systems for the creation of intangible managerial accounting information: An exploratory study. RBGN-Revista Brasileira de Gestão de Negocios, 12(37), 161-174. https://doi.org/10.7819/rbgn.v10i27.281

Appah, E. (2018). Fair value accounting \& challenges of audit practice in Nigeria. Research Journal of Finance and Accounting, 9 (14), 16-24

Ball, R. (2006). International Financial Reporting Standards (IFRS): Pros and cons for investors. Accounting and Business Research. International Accounting Policy Forum, 5-27. Available in http://eprints.dinus. ac.id/14784/1/International_Financial_Reporting_Standards_(IFRS)_pros_and_cons_for_investors.pdf (consulted 25/09/2017)

Barker, R., \& Schulte, S. (2017). Representing the market perspective: Fair value measurement for non-financial assets. Accounting, Organizations and Society, 56, 55-67. https://doi.org/10.1016/j.aos.2014.12.004

Barth, M. E. (1994). Fair value accounting: Evidence from investment securities and market valuation. The Accounting Review, 69 (1), 1-25.

Barth, M., \& Landsman, W. (1995). Fundamental issues related to using fair value accounting for financial reporting. Accounting Horizons, 9(4), 97-107.

Bell, T. B., \& Griffin, J. B. (2012). Commentary on auditing high-uncertainty fair value estimates. Auditing: A Journal of Practice \& Theory, 3(1), 147-155

Bessong, P.K., \& Charles, E. (2012). Comparative analysis of fair value and historical cost accounting on reported profit: A study of selected manufacturing companies in Nigeria. Research Journal of Finance and Accounting, 3 (8), 132-149.

Biondi, Y., \& Suzuki, T. (2007). Socio-economic impacts of international accounting standards: An introduction. Socio-Economic Review, 5(1), 585-602. https://doi.org/10.1093/ser/mwm011

Blanchette, M. \& Desfleurs, A. (2011). Critical perspectives on the implementation of IFRS in Canada. Journal of Global Business Administration, 3(1),1-35.

Bloom, R., \& Schirm, D. (2008). An Analysis of the GAO Study on Audit Market Concentration. Available in: http:// www.cpajournal.com/2008/408/perspectives/p6.htm (consulted 11/01/2017)

Botosan, C.A., Beatty, A.L., Hopkins, P.E., Nelson, K.K., \& Venkatachalam, M. (2005). Response to the FASB's exposure draft on fair value measurements. Accounting Horizons, 19 (3), 187-196.

Bougen, P.D., \& Young, J.J. (2012). Fair value accounting: Simulacra and simulation. Critical Perspectives on Accounting, 23(4-5), 390-402. https://doi.org/10.1016/j.cpa.2011.05.004

Cannon, N.H., \& Bedard, J.C. (2017). Auditing challenging fair value measurements: Evidence from the field. The Accounting Review, 92 (4), 81-114. https://doi.org/10.2308/accr-51569

Cardao-Pito, T. (2016). A law for the social sciences regarding us human beings. Journal of Interdisciplinary Economics, 28(2), 202-229. https://doi.org/10.1177/0260107916643471

Cardao-Pito, T., \& Barros, J. (2016). The application of "fair value" accounting standards to the income statements of companies listed in the Portuguese Stock Index-20 (PSI-20). Revista Brasileira De Gestão De Negócios, 18(59), 67-86. http://dx.doi.org/10.7819/rbgn.v18i59.2470 
Carroll, T., Linsmeier, T., \& Petroni, K. (2003). The reliability of fair value versus historical cost information: Evidence from closed-end mutual funds. Journal of Accounting, Auditing \& Finance, 18 (1), 1-24

Chouinard, E., \& Youngman, P. (2008). Fair value accounting and financial stability. Bank of Canada Report. Available in http://www.bankofcanada.ca/wp-content/uploads/2012/01/fsr-1208-chouinard.pdf (consulted $12 / 11 / 2017)$

Chua, W.F., \& Taylor, S.L. (2008). The rise and rise of IFRS: An examination of IFRS diffusion. Journal of Accounting and Public Policy 27(6):462- 473. https://doi.org/10.1016/j.jaccpubpol.2008.09.004

Danbolt, J., \& Rees, W. (2008). An experiment in fair value accounting: UK Investment Vehicles. European Accounting Review, 17(2), 271-303. https://doi.org/10.1080/09638180701819865

Deloitte (2012). iGAAP 2012: A guide to IFRS reporting, Volume A, Part 1. (5 $5^{\text {th }}$ Ed.). London, Edinburg: LexisNexis.

Ekiran, O. (2000). Understanding the capital market. McGraw-Hill Publisher.

Emett, S.A., Libby, R., \& Nelson, M.W. (2018). PCAOB guidance and audits of fair values for Level 2 investments. Accounting, Organizations and Society, 71, 57-72. https://doi.org/10.1016/j.aos.2018.05.011

Enahoro, J.A., \& Jayeoba, J. (2013). Value measurement and disclosures in fair value accounting. Asian Economic and Financial Review, 3 (9), 1170-1179.

Gill, G. \& Cossert, G. (2008). Modern Auditing in Australia (4thed.) Australia: John Wiley and Sons.

Glover, S., Taylor, M., \& Wu, Y. (2016). Current practices and challenges in auditing fair value measurements and complex estimates: Implications for auditing standards and the academy. Working paper, Brigham Young University, Case Western Reserve University, and Texas Tech University.

Glover, S.M., Taylor, M.H., \& Wu, Y. (2014). Closing the gap between auditor performance and regulators' expectations when auditing fair value measurements: Evidence from practicing audit partners. Working Paper, Deloitte Foundation.

Griffin, J. B. (2014). The effects of uncertainty and disclosure on auditors' fair value materiality decisions. Journal of Accounting Research, 52(5), 1165-1193. https://doi.org/10.1111/1475-679X.12059.

Griffith, E., Hammersley, J. S., \& Kadous, K. (2015). Audits of complex estimates as verification of management numbers: How institutional pressures shape practice. Contemporary Accounting Research, 32 (3): 833-863. https://doi.org/10.1111/1911-3846.12104

Guthrie, K., Irving, J. H., \& Sokolowsky, J. (2011). Accounting choice and the fair value option. Accounting Horizons, 25(3), 487-510. https://doi.org/10.2308/acch-50006.

Hague, I. (2002). Fair value for financial instruments: Where to next? Balance sheet, 10, 8-12

Hermanson, R., Shrawer, R. \& Shrawer, J. (1993) Auditing Theory and Practice (3 ${ }^{\text {rd }}$ ed.). Boston, US: Homewood Publishers.

Hux, C.T. (2017). Use of specialists on audit engagements: A research synthesis and directions for future research. Journal of Accounting Literature, 39, 23-51. https://doi.org/10.1016/j.acclit.2017.07.001

International Auditing and Assurance Standards Board, IAASB. (2008). Staff audit practice alert: Challenges in auditing fair value estimates in the current market environment. Available in http://www.ifac.org/system/files/ downloads/Staff_Audit_Practice_Alert.pdf (consulted 17/08/2017)

Ijeoma, N. B. (2014). The contribution of fair value accounting on corporate financial reporting in Nigeria. American Journal of Business, Economics and Management, 2(1), 1-8.

International Accounting Standards Board, IASB (2012). IFRS 13 Technical summary.

International Auditing and Assurance Standards Board, IAASB. (2008). Staff audit practice alert: Challenges in auditing fair value estimates in the current market environment. Available in http://www.ifac.org/system/files/ downloads/Staff_Audit_Practice_Alert.pdf (consulted 17/08/2017)

International Standard on Auditing, ISA 540 (Revised). (2018). Auditing Accounting estimates and related disclosures. Available in International Auditing and Assurance Standards Board, (IAASB) website https://www. iaasb.org/publications/isa-540-revised-auditing-accounting-estimates-and-related-disclosures-9 (consulted 17/08/2017) 


\section{B. Oyewo / Contaduría y Administración 66(2) 2021, 1-33 \\ http://dx.doi.org/10.22201/fca.24488410e.2021.2178}

Jafaru, J., \& Shodipo, M. (2013). Accounting academics perception of the use of fair value accounting in Nigeria. Accounting Frontier, 4(2), 103-119

Jayeoba, O., \& Ajibade, A. (2016). Evolution of accounting standards in Nigeria: A historical perspective. International Journal of Advanced Academic Research, 2(8), 9-24.

Jermakowicz, E., \& Gornik-Tomaszewski, S. (2006). Implementing IFRS from the perspective of EU publicly traded companies. Journal of International Accounting, Auditing and Taxation, 15(1), 170-196. https://doi. org/10.1016/j.intaccaudtax.2006.08.003

Joe, J.R., Vandervelde, S.D., \& Wu, Y. (2017). Use of high quantification evidence in fair value audits: Do auditors stay in their comfort zone?. The Accounting Review, 92 (5), 89-116. https://doi.org/10.2308/accr-51662

Kaplan (2015). CIMA study text for Paper F1: Financial Reporting and Taxation. Berkshire, UK: Kaplan Publishing

Klibi, M. (2016). Using international standards as a complement to overcome the unachieved nature of local GAAPs. Journal of Applied Accounting Research, 17 (3), 356-376. https://doi.org/10.1108/JAAR-07-20140071

Kumarasiri, J., \& Fisher, R. (2011). Auditors' perceptions of fair value accounting: Developing country evidence. International Journal of Auditing, 15(1), 66-87. https://doi.org/10.1111/j.1099-1123.2010.00423.x

Landsman, W.R. (2007). Is fair value accounting information relevant and reliable? Evidence from capital market research. Accounting and Business Research, 37(3), 19-30. https://doi.org/10.1080/00014788.2007.9730081

Laux C., \& Leuz, C. (2009). The crisis of fair value accounting: Making sense of the recent debate. Accounting, Organizations and Society, 34(1), 826-834. https://doi.org/10.1016/j.aos.2009.04.003

Maruli, S., \& Farahmita, A. (2011). The analysis of application of fair value and historical cost approaches in the valuation of biological assets in the agricultural companies. Asia Pacific Journal of Accounting and Finance, 1 (2), 133-149.

Melville, A. (2011). International financial reporting: A practical guide. (4 ${ }^{\text {th }}$ Ed.). Essex, England: Pearson Education Limited.

Ministry of Economics, Japan. (2014). Ito review of competitiveness and incentives for sustainable growth: Building favorable relationships between companies and investors. Available in: http://www.meti.go.jp/english/ press/2014/pdf/0806_04b.pdf (consulted 25/09/2017)

Mirza, A., Orrel, M., \& Holt, G. (2008). Practical Implementation guide and workbook. (2nd Ed.). Willey IFRS: Edition.

Mwape, K.A. (2010). Lessons learned from implementing IFRS: A regulators perspective. Bank of Zambia, July, 2010.

Nelson, K. K. (1996). Fair value accounting for commercial banks: An empirical analysis of SFAS No. 107. The Accounting Review, 71 (April), 161-182.

Nwankwo, G.O. (1988). The Nigeria Financial System. Lagos: Macmillan Publishers Ltd.

Okafor, C., \& Ogiedu, K. O. (2012). Perceptions of fair value accounting: Evidence from Nigeria. JORIND, 10 (3), 417-432. https://doi.org/10.4314/jorind.v10i3

Okaro, S.C., \& Okafor, G.O. (2013). Audit market concentation in Nigeria: An empirical study. Accounting Frontier, 4 (2), 264-276.

Osaze, B.E., \& Anao, A.R. (1999). Managerial Finance. Benin City: UniBen Press.

Oyewo, B.M. (2020). Post-implementation challenges of fair value measurement (IFRS 13): Some empirical evidence. African Journal of Economic and Management Studies. https://doi.org/10.1108/AJEMS-05-2019-0183

Oyewo, B., Emebinah, E. \& Savage, R. (2020). Challenges in auditing fair value measurement and accounting estimates: Some evidence from the field. Journal of Financial Reporting and Accounting, 18 (1), 51-75. https:// doi.org/10.1108/JFRA-01-2019-0002

Pacter, P. (2007) "Fair value under IFRS: Issues for developing countries and SMEs, in The Routledge Companion to Fair Value and Financial Reporting, (ed).” Walton, P, London: Routledge, 350-369. 


\section{B. Oyewo / Contaduría y Administración 66(2) 2021, 1-33}

http://dx.doi.org/10.22201/fca.24488410e.2021.2178

Petroni, K. R., \& Wahlen J. M. (1995). Fair values of equity and debt securities and share prices of property-liability insurers. Journal of Risk and Insurance, 62 (4), 719-737. https://doi.org/10.2307/253592

Procházka, D. (2011). The role of fair value measurement in the recent financial crunch. Prague Economic Papers, 1,71-88. https://doi.org/10.18267/j.pep.388

Riauhi-Belkaoui, A. (2004). Accounting theory (5th ed.). Singapore: Seng Lee Press.

Rogers, E.M. (2003). Diffusion of innovations (5th ed.). New York: The Free Press

Ting, Y.S., \& Soo, C.M. (2005). Fair value accounting: Relevance, reliability and progress in Malaysia. Available in http://alanyoonassociates.com/news/fairValueAccounting.pdf (consulted 25/09/2017)

Umoren, A., \& Enang, E. (2015). IFRS adoption and value relevance of financial statements of Nigerian listed Banks. International Journal of Finance and Accounting, 4(1), 1-7

Volha, S. (2010). Fair value accounting. (BS-Thesis) submitted to Faculty of Business Administration, University of Iceland. Available in https://skemman.is/bitstream/1946/4234/1/Thesis_fixed.pdf (consulted 17/08/2017)

Watts, R.L. (2006). What has The Invisible Hand Achieved? Accounting and Business Research, 36 (special issue, 2006): 51-61. https://doi.org/10.1080/00014788.2006.9730046

Yahaya, K. A., Fagbemi, T. O., \& Oyeniyi, K. K. (2015). Effect of international financial reporting standards on the financial statements of Nigerian banks. Journal of Agricultural Economics, Environment and Social Sciences $1(1), 18-29$.

Yichao, L. (2010). The study of the application status of fair value accounting in China. International Journal of Business and Management, 5(9), 21-33

Zack, G.M. (2009). Fair Value Accounting Fraud: New Global Risks and Detection Techniques Hoboken, New Jersey: John Wiley \& Sons, Inc.

\section{Annex}

Table A1

KMO and Bartlett's Test Results

\begin{tabular}{c|c|c|c}
\hline \multicolumn{2}{c|}{} & $\begin{array}{c}\text { Areas of } \\
\text { Application }\end{array}$ & $\begin{array}{c}\text { Valuation } \\
\text { Methods }\end{array}$ \\
\hline Kaiser-Meyer-Olkin Measure of Sampling Adequacy. & .711 & .705 \\
\hline \multirow{3}{*}{$\begin{array}{c}\text { Bartlett's Test of } \\
\text { Sphericity }\end{array}$} & Approx. Chi-Square & 1205.653 & 967.328 \\
\cline { 2 - 4 } & df & 45 & 45 \\
\cline { 2 - 4 } & Sig. & .000 & .000 \\
\hline
\end{tabular}

